\title{
LLC REZONÁNS KONVERTER TERVEZÉSE ÉS SZIMULÁLÁSA
}

\author{
Boros Rafael Ruben \\ tanársegéd, Miskolci Egyetem, \\ Fizikai és Elektrotechnikai Intézet, Elektrotechnikai és Elektronikai Intézeti Tanszék \\ H-3515 Magyarország, Miskolc-Egyetemváros, e-mail: elkruben@uni-miskolc.hu
}

\begin{abstract}
Absztrakt
A kutatás bemutatja az LLC rezonáns feszültségnövelö konverter tervezését és szimulációját, amelynek a bemenete közvetlenül napelemre, kimenete pedig háromfázisú inverterre csatlakozik. A háromfázisú inverter aszinkron motoros hajtást valósit meg. A konverter kimeneti feszültségét szabályozókör állítja be, ennek a dinamikusságát is vizsgálja a kutatás. A tanulmány röviden ismerteti az LLC konvertert általánosan, kifejti részletesebben a rezonáns elemek értékeinek tervezését, majd a tervezett paraméterek alapján elkészült szimuláció eredményét is. A szimuláció MATLAB alapú grafikus fejlesztökörnyezetben valósult meg (Simulinkben).
\end{abstract}

Kulcsszavak: rezonáns konverter, LLC konverter, egyenáramú szaggató, napelem, aszinkron motoros hajtás, MATLAB, Simulink

\begin{abstract}
The research presents the design and simulation of an LLC resonant voltage boost converter that produces medium voltage level from low voltage level. The input of the converter is connected directly to a solar cell, and its output is also directly to a three-phase inverter, which implements an induction motor drive. The study briefly describes the operation of the LLC converter, explains in more detail the design of the values of the passive elements, and then the result of the simulation based on the designed parameters. The simulation was implemented in a MATLAB based graphical development environment (Simulink).
\end{abstract}

Keywords: resonant converter, LLC converter, DC chopper, solar cell, induction motor drive, MATLAB, Simulink

\section{Bevezetés}

Napjainkban széleskörben nem használatosak a napelemröl táplált aszinkron motoros hajtások. Ennek számos oka van, mint például: a motor indításához 6-8-szor nagyobb indítóáram kell, mint a névleges áram. Továbbá a napelemekhez használt MPPT (Maximum Power Point Tracking) algoritmusok nem alkalmazkodnak jó hatásfokkal a dinamikus fogyasztókhoz (pl. motorok). Azonban kisebb teljesítményü motorok esetén érdemes megfontolni a napelemről való ellátás alkalmazását, leginkább szigetüzemü alkalmazásokban. Ilyenre példák lehet a szivattyús alkalmazások, ahol nem áll rendelkezésre közcélú hálózat [4].

Az aszinkron motorok váltakozóáramú fogyasztók, általában háromfázisú kivitelüek. A kisebb teljesítményü motoroknak (2,2 kW-ig) a névleges feszültségük csillag kapcsolásban tipikusan 380-400 V, delta kapcsolásban pedig 220-230 V. Probléma adódik azáltal, hogy a napelem panelek vagy sztringek maximális munkaponti feszültsége változik a fényintenzitás függvényében, valamint az egyenfeszültség nagysága eltér a motor feszültségétől (kisebb). Ezért alkalmazni kell egy DC/DC 
konvertert, amely a napelem feszültségét feltranszformálja, majd ez a feszültség jut a közbenső egyenáramú körbe, ami a motort tápláló inverterre kerül. Az inverter egyenfeszültségből váltakozó feszültséget állít elő, tetszőlegesen változtatható frekvenciával, tehát az inverter egy speciális DC/AC konverter, amely az aszinkron motor fordulatszámát is képes változtatni.

\section{Az LLC rezonáns konverter általánosan}

A kapcsolóüzemü tápegységek, mint az LLC konverter is, széles körben elterjedtek, melynek oka a nagy hatásfok és a relatív kicsi geometriai méret. A kapcsolóüzemü tápegységek tartalmaznak egy nagyfrekvenciás transzformátort, vagy csatolt induktivitást, típustól függően. Számos kapcsolóüzemü átalakító létezik, amelyek más-más célokhoz alkalmazkodnak gazdaságosan. A kapcsolási frekvencia növelésével a transzformátor mérete csökkenthetö, ámbár a félvezetök nagyobb kapcsolási hőveszteséggel müködnek ilyenkor, amely nagyobb hütési igényt, nagyobb hütőbordát eredményez.

A rezonáns átalakítókkal a kapcsolási veszteség nagymértékben csökkenthető. A rezonáns konverterek esetén a félvezetők kapcsolása olyankor történik, amikor a kapcsolóelemen a feszültségesés zérus (ZVS: Zero Voltage Switching), vagy az átfolyó áram zérus (ZCS: Zero Current Switching). Ezek a kapcsolási módok lágy (soft) kapcsolást eredményeznek a félvezetőn, így a dinamikus teljesítményveszteség nagymértékben lecsökken a félvezetőn [3].

Érdemes az 1. ábrán látható LLC teljes-hidas konvertert alkalmazni a kitüzött feladat esetében [1]. Nagy előnye az LLC konverternek, hogy széles skálán változó terhelés esetén, csak szük intervallumon kell a kapcsolási frekvenciát módosítani, emiatt jól szabályozható terhelés nélkül vagy nagyon alacsony terhelés esetén is. ZVS üzemmódban müködtethető, aminek az előbb felsoroltak kívül további előnye, hogy kicsi a kibocsátott EMI (elektromágneses interferencia) a lágy kikapcsolás miatt.

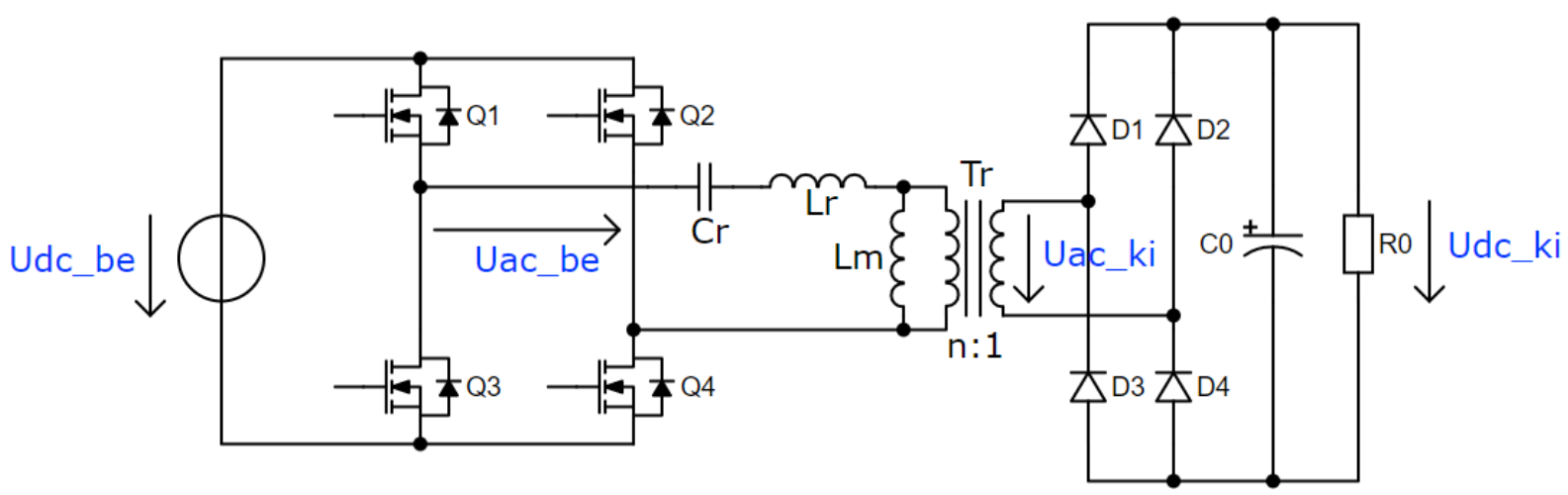

\section{1. ábra. LLC rezonáns átalakitó}

Két mágneses komponens szükséges a rezgőkörhöz: az $\mathrm{L}_{\mathrm{r}}$ és $\mathrm{L}_{\mathrm{m}}$ induktivitások. $\mathrm{Az} \mathrm{L}_{\mathrm{r}}$ a soros rezonáns induktivitást, az $\mathrm{L}_{\mathrm{m}}$ a mágnesező induktivitást jelöli, amely sönt jellegü. A $\mathrm{C}_{\mathrm{r}}$ pedig a soros rezonáns kapacitást jelenti. Transzformátort is szükséges beépíteni a nagy erősítés érdekében. Integrált transzformátor segítségével az $\mathrm{L}_{\mathrm{r}}$ és $\mathrm{L}_{\mathrm{m}}$ induktivitások implementálhatók.

Tekintsük a 2. ábrát, amely az 1. ábrába behelyettesíti a transzformátor valóságos paramétereit, azaz a szórt primer és szekunder, valamint a mágnesező induktivitását. Továbbá leegyszerüsíti az 1. ábrát. Az ábra alján az egyszerüsített hálózatban a transzformátor már ideálisnak tekinthető. Az LLC konverterek múködését a szórt induktivitások $\left(\mathrm{L}_{\mathrm{s} 1}, \mathrm{~L}_{\mathrm{s} 2}\right)$ is nagymértékben befolyásolják. Ámbár a szórt induktivitások mérése a gyakorlatban igen nehézkes, de a hálózat egyszerüsítése után erre már nincs 
szükség. Az $\mathrm{L}_{\mathrm{p}}$ paramétert gyakorlatban méréssel határozhatjuk meg úgy, hogy a transzformátor primer tekercselésén megmérjük az induktivitást, miközben a szekunder oldal nyitott. $\mathrm{Az} \mathrm{L}_{\mathrm{r}}$ paramétert hasonlóan, rövidrezárt szekunder tekercs esetén mérjük.

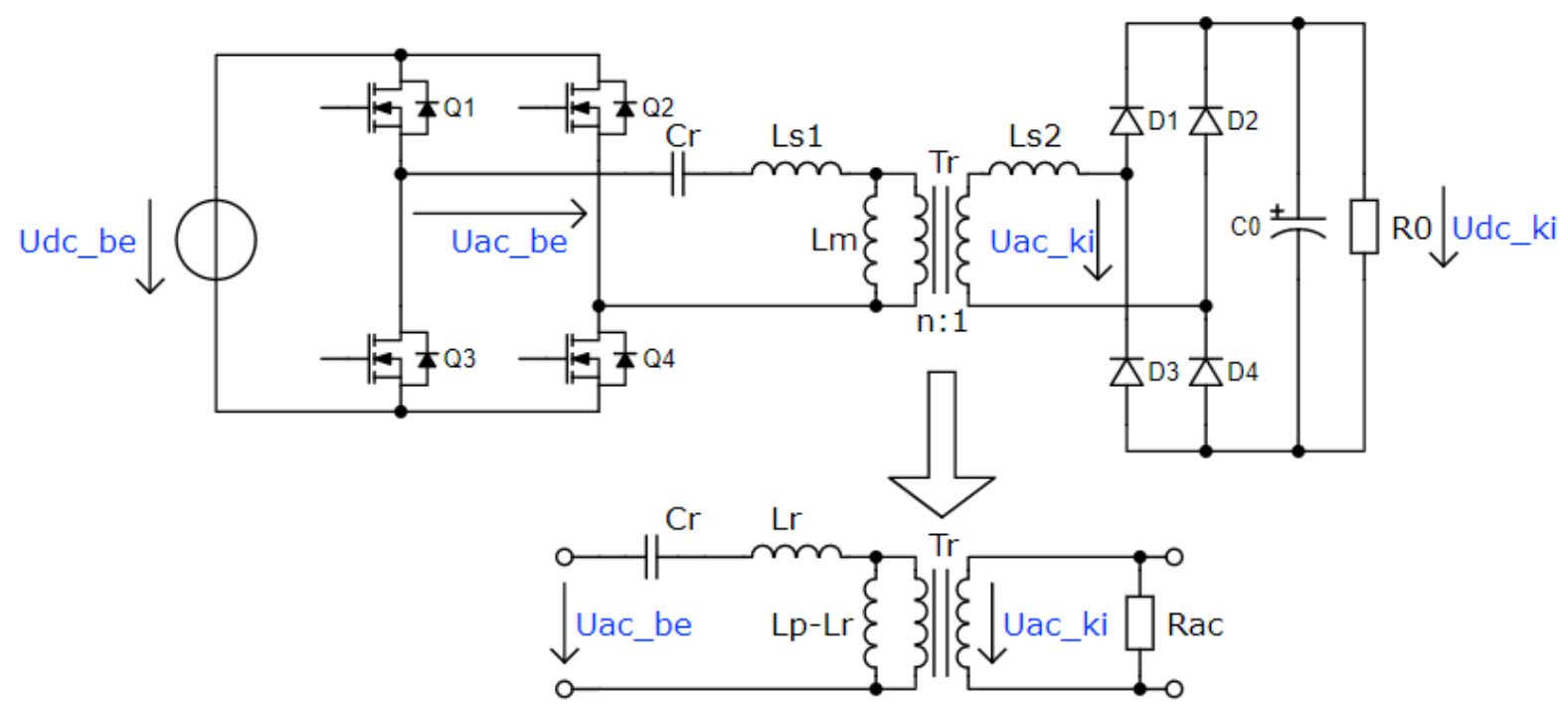

2. ábra. LLC rezonáns átalakitó egy valóságos transzformátor szórt és mágnesezö induktivitásával, a kapcsolás egyszerüsitése

Az $L_{\mathrm{r}}$ (rezonáns induktivitás) paraméter megjelenése tehát az egyszerüsítésből fakad, amelyet az 1 . képlet szerint lehet meghatározni [2].

$$
L_{r}=L_{s 1}+L_{m} \times\left(n^{2} L_{s 2}\right)=L_{s 1}+L_{m} \times L_{s 1}
$$

Létrejön továbbá az $L_{p}$ paraméter (primer induktivitás), amely a primer szórt induktivitás és a mágnesező induktivitás össze (2. képlet) [2].

$$
L_{p}=L_{s 1}+L_{m}
$$

A mágnesező induktivitás a 3. képlet alapján megadható, csupán az előzőekben említett transzformátoron végzett mérés eredményének két értéke szükséges hozzá [2].

$$
L_{m}=L_{p}-L_{r}
$$

Az LLC konverterek tervezésénél fontos statikus paraméter az $m$ paraméter, amelynek változtatásával lehet optimalizálni a konvertert (4. képlet). Ennek a paraméternek a csökkentése maga után vonja: a konverter hatásfokának csökkentését, nagyobb erősítést a kimeneten, keskenyebb frekvencia intervallumot a szabályozáshoz. Az $m$ paraméter növelése pedig azt eredményezi, hogy nagyobb lesz a konverter hatásfoka azáltal, hogy kisebb mágnesező cirkuláló áram folyik [1].

$$
m=\frac{L_{p}}{L_{r}}=\frac{L_{r}+L_{m}}{L_{r}}
$$

A 2. ábrán látható még egy $\mathrm{R}_{\mathrm{AC}}$ ellenállás is, amely váltakozó áramú oldalról vizsgált terhelésnek felel meg. Itt az $\mathrm{R}_{0}$ az egyenáramú terhelést, az Av pedig a virtuális erősítést jelenti [2]. 


$$
R_{A C}=\frac{8}{\pi^{2}} \cdot \frac{R_{0}}{A_{v}^{2}}
$$

Két rezonancia frekvencia létezik, ezek a Thomson-képletböl adódnak (6. képlet és 7. képlet). Az első rezonancia frekvenciát az $\mathrm{L}_{\mathrm{r}}, \mathrm{C}_{\mathrm{r}}$ értékek, a másodikat pedig az $\mathrm{L}_{\mathrm{p}}$ és $\mathrm{C}_{\mathrm{r}}$ értékek határozzák meg [2].

$$
\begin{aligned}
& f_{r}=\frac{1}{2 \pi \sqrt{L_{r^{\prime} C_{r}}}} \\
& f_{p}=\frac{1}{2 \pi \sqrt{L_{p} \cdot C_{r}}}
\end{aligned}
$$

A rezgőkör jósági tényezőjét a 8 . képlet írja le [1].

$$
Q=\frac{\sqrt{\frac{L_{r}}{C_{r}}}}{R_{A C}}
$$

A 9. képlet megadja a 2. ábrán látható egyszerüsített hálózat átviteli függvényét [1]. Az $\mathrm{F}_{\mathrm{n}}$ együttható a normalizált frekvenciát jelenti, amely a rezgőkört tápláló feszültség frekvenciájának és a rezonancia frekvenciának a hányadosa (10. képlet) [1].

$$
\begin{gathered}
A\left(Q, m, F_{n}\right)=\left|\frac{U_{A C \_K I}(s)}{U_{A C_{B E}}(s)}\right|=\frac{F_{n}^{2}(m-1)}{\sqrt{\left(m \cdot F_{n}^{2}-1\right)^{2}+F_{n}^{2} \cdot\left(F_{n}^{2}-1\right)^{2} \cdot(m-1) \cdot Q^{2}}} \\
F_{n}=\frac{f_{s}}{f_{r}}
\end{gathered}
$$

Az átviteli függvény grafikus megjelenítését a 3. ábra végzi, amelyen példaként $\mathrm{m}=5$-re lett beállítva. Különböző terhelések esetén kapunk képet az erősítés nagyságáról, a normalizált frekvencia függvényében.

Ha a terhelés nő ( $\mathrm{R}_{\mathrm{AC}}$ csökken), akkor $\mathrm{Q}$ is növekszik. Egyre nagyobb terhelés esetén a görbe maximuma $\mathrm{A}=1$-hez konvergál, azaz a rezonancia frekvencián táplált rezgőkör erősítése $\mathrm{A}=1$ lesz. Ellenben, ha a terhelés csökken, akkor a görbék maximuma a primer rezonancia frekvenciához $\left(f_{p}\right)$ tartanak. A rezonancia frekvenciában létrejövő $\mathrm{A}=1$ erősítés csak akkor igaz, ha a transzformátor szekunder szórt induktivitását nem vesszük figyelembe, ellenben az erősítés kissé megváltozik. A rezonancia frekvenciában megjelenik a virtuális erősítés, melyet $A_{v}$-vel jelölünk (11. képlet) [2].

$$
A_{V}=\sqrt{\frac{L_{p}}{L_{p}-L_{r}}}=\sqrt{\frac{m}{m-1}}
$$

\section{A konverter méretezése, a jósági tényező meghatározása}

Tekintsük a 4. ábrát, amelyen látható a céláramkör sematikus ábrája. A bal oldalon a DC bemenet, a napelem található pufferkondenzátorral. Ez az egyenfeszültség táplálja az egyfázisú invertert, amely $50 \%$ kitöltési tényező mellett állít elő váltakozó feszültséget $\mathrm{f}_{\mathrm{s}}$ frekvencián (DC/AC). A rezgőkör és a transzformátor feltranszformálja a feszültséget a kívánt értékre (AC/AC). A váltakozó feszültség teljes-

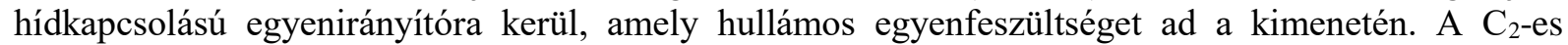
kondenzátor simítja az egyenfeszültség hullámosságát. A sima egyenfeszültség a közbenső egyenáramú körre kerül, amely a háromfázisú invertert táplálja, ez váltakozó feszültséget állít elő a motort számára (DC/AC). Mivel a motor változó dinamikusan terhelés, ezért figyelni kell a közbenső kör feszültségét, amelyre rászabályoz az egyfázisú inverter. A dinamikusan változó terhelés miatt a jósági tényező, így az erősítés is megváltozik. Ezt figyeli leválasztó erősítőn keresztül a rezgőkört vezérlő áramkör. A 
vezérlő úgy szabályozza a frekvenciát, hogy az alapjelként beállított $330 \mathrm{~V}$ legyen a kimeneten. Dinamikusan változik eközben a napelem munkaponti feszültsége is a változó fényintenzitás miatt.

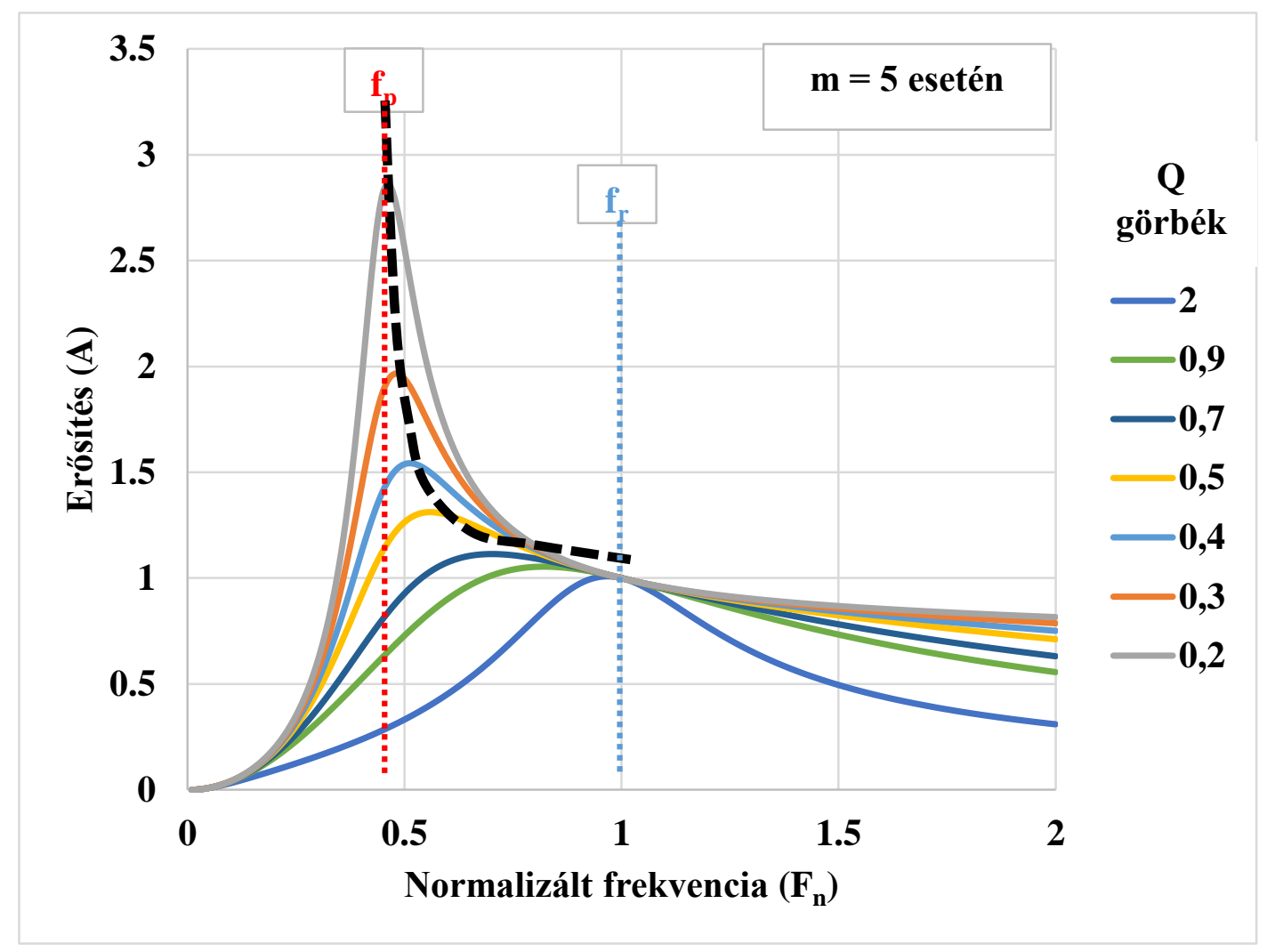

3. ábra. Az erösités a normalizált frekvencia függvényében, különbözö terhelések esetén

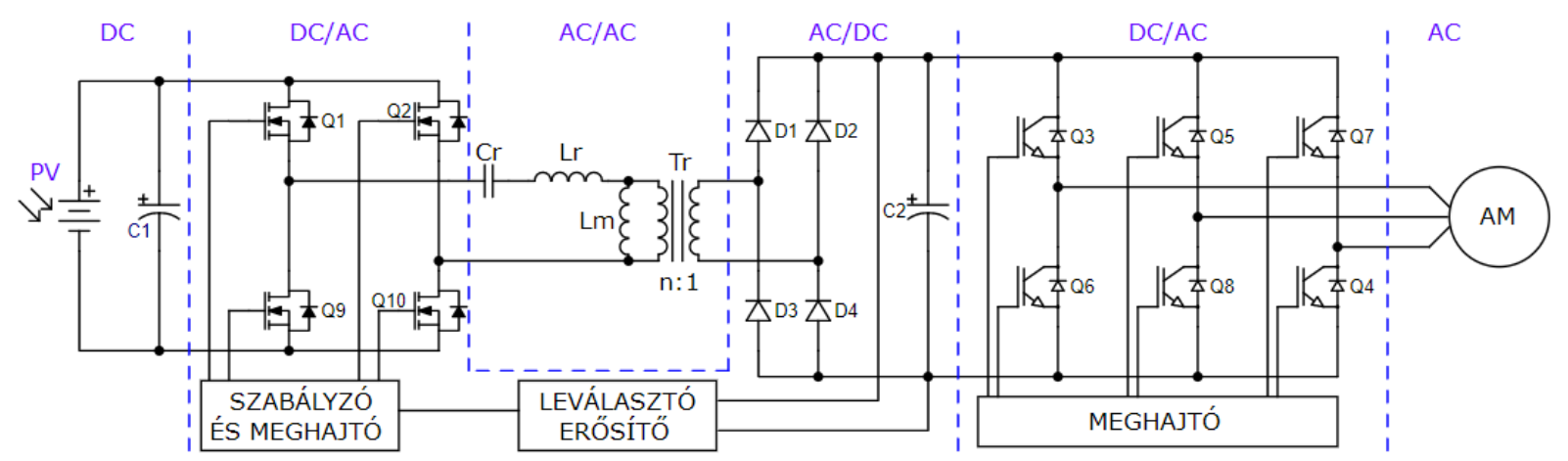

4. ábra. A céláramkör sematikus ábrája

Az első lépés a konverter tervezésénél, hogy megadjuk a bemeneti paramétereket. Tudni kell, hogy mekkora teljesítmény szükséges a kimeneten. A tanulmány célja háromfázisú törpe aszinkron motorok táplálása, így a kiválasztott kimeneti teljesítmény $400 \mathrm{~W}$ (12. képlet).

$$
P_{0}=400 \mathrm{~W}
$$


A kimeneti feszültség az egyenáramú közbenső körben $330 \mathrm{~V}$ kell, hogy legyen, így elöállítható $230 \mathrm{~V}$ effektív feszültség az inverter kimenetén a motor számára, beleszámítva a veszteségeket. A motort ekkor delta kapcsolásban kell bekötni. Ennélfogva kiszámítható az egyenáramú oldalon folyó áram nagysága és az egyenáramú terhelés nagysága (13. és 14. egyenlet).

$$
\begin{aligned}
& I_{D C_{-} K I}=\frac{P_{0}}{U_{D C_{-} K I}}=\frac{400}{330}=1,2121 \mathrm{~A} \\
& R_{0}=\frac{U_{D C_{-} K I}}{I_{D C_{-} K I}}=\frac{330}{1,2121}=272,26 \Omega
\end{aligned}
$$

Szükséges bemeneti paraméter továbbá a bemeneti feszültség maximuma, illetve minimuma. A hálózatot olyan napelem táplálja, amelynek maximális munkaponti (nominális) feszültsége $29 \mathrm{~V}$ körül adódik és legnagyobb teljesítménye $500 \mathrm{~W}, 1000 \mathrm{~W} / \mathrm{m}^{2}$ mellett. Alsó határnak $25 \mathrm{~V}$, felső határnak 40 V lett meghatározva. Ezek alapján meghatározható a transzformátor áttétele (15. képlet). Szükséges hozzá a virtuális erősítés értéke, melyet már a 11. egyenletben említett a tanulmány. Az eredményt a 15. képlet adja. Az $m$ paraméter ezen kutatásban 8-ra lett megválasztva a jó hatásfok érdekében. $U_{\mathrm{F}}$ egy dióda nyitóirányú feszültségesését jelenti az egyenirányító hídkapcsolásban.

$$
\begin{gathered}
n=\frac{U_{D C_{-} B E_{-} M A X}}{U_{D C_{-} K I}+2 U_{F}} \cdot A_{\text {min }}=\frac{40}{330+2 \cdot 1,5} \cdot 1,0691=0,128414 \\
A_{\text {min }}=A_{V}=\sqrt{\frac{m}{m-1}}=\sqrt{\frac{8}{8-1}}=1,0691
\end{gathered}
$$

A maximális erősítést szükséges meghatározni továbbá, amikor a bemeneti feszültség a legkevesebb (25 V ez esetben). Ehhez a 17. egyenlet felhasználható.

$$
A_{\text {max }}=A_{\text {min }} \cdot \frac{U_{D C_{-} B E_{-} M A X}}{U_{D C_{-} B E_{-} M I N}}=1,0691 \cdot \frac{40}{25}=1,7104
$$

A következőkben úgy meg megválasztani a jósági tényező értékét $(\mathrm{Q})$, hogy elérjük a maximális erősítés értékét. Ehhez az szükséges, hogy az átviteli függvénybe behelyettesítsük a kezdeti értékeket, ábrázoljuk a kapott függvényt, majd ennek megkeressük a maximumát (érdemes grafikusan excelben). Addig iteráljuk Q értékét, még a függvény maximuma meghaladja az $\mathrm{A}_{\max }$ értékét. Azonban fontos megemlíteni, hogy a függvény maximumában alkalmazott kapcsolási frekvencia esetén a félvezető kapcsolóelemek nem ZVS üzemmódban müködnek, így a hatásfok nagymértékben lecsökken. Ilyenkor egy $10 \%$-kal érdemes megnövelni az $\mathrm{A}_{\max }$ értékét. Az iterációk során $\mathrm{Q}=0,232$ érték adódott, ezzel lefedve a $10 \%$-kos túlméretezést. $\mathrm{Q}=0,232$ jósági tényezővel, $\mathrm{m}=8$-as statikus paraméterrel adódik az 5. ábrán látható átviteli függvény. Látható továbbá az ábrán a minimális és maximális erősítés igénye (túlméretezés nélkül). A függvény maximuma $F_{n}=0,38$-nál jelenik meg.

Továbbá meg kell adni, hogy mekkora legyen a rezonancia frekvencia $\left(\mathrm{f}_{\mathrm{r}}\right)$ értéke. Ezt az értéket a félvezetők tulajdonságai és a vezérlőáramkör képességei korlátozzák. Legfeljebb $100 \mathrm{kHz}$-es frekvencia még elfogadható, SiC MOSFET-ekkel, megfelelő meghajtókkal és nagysebességü mikrovezérlővel, így a továbbiakban $\mathrm{f}_{\mathrm{n}}=100 \mathrm{kHz}$. Így tehát a legnagyobb erösítés $38,6 \mathrm{kHz}$-nél van.

A kapacitív és mágneses paraméterek meghatározásához a 18, 19, 20. egyenletek szükségesek, valamint a váltakozó áramú oldalról vizsgált terhelés értéke is. (22. képlet). A mágnesező induktivitást a 21. képlet adja.

$$
C_{r}=\frac{1}{2 \cdot \pi \cdot Q \cdot f_{r} \cdot R_{A C}}=\frac{1}{2 \cdot \pi \cdot 0,232 \cdot 10^{5} \cdot 3,1842}=2154 n F
$$




$$
\begin{gathered}
L_{r}=\frac{1}{\left(2 \cdot \pi \cdot f_{r}\right)^{2} \cdot C_{r}}=\frac{1}{\left(2 \cdot \pi \cdot 10^{5}\right)^{2} \cdot 2154 \cdot 10^{-9}}=1,1756 \mu \mathrm{H} \\
L_{p}=m \cdot L_{r}=8 * 1,1756=9,405 \mu \mathrm{H} \\
L_{m}=L_{p}-L_{r}=9,405-1,1756=8,2294 \mu \mathrm{H} \\
R_{A C}=\frac{8}{\pi^{2}} \cdot \frac{N_{p}{ }^{2}}{N_{s}{ }^{2}} \cdot R_{0}=\frac{8 \cdot n^{2}}{\pi^{2}} \cdot \frac{U_{D C_{K I}}{ }^{2}}{P_{0}}=\frac{8 \cdot 0,128414^{2}}{\pi^{2}} \cdot \frac{330^{2}}{400}=3,1842 \Omega
\end{gathered}
$$

Ezzel a tervezés befejeződött, a továbbiakban a kapott eredmények alapján a szimuláció bemutatása következik Simulinkben.

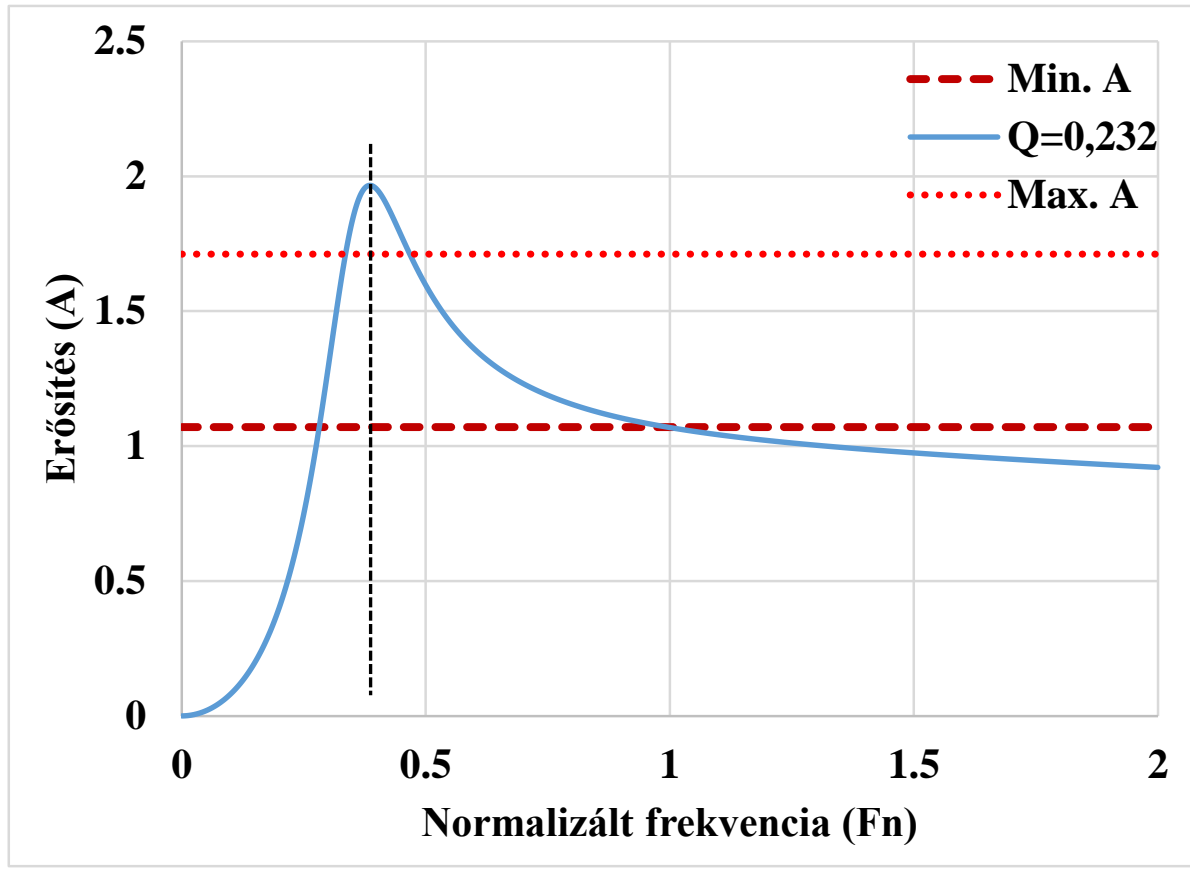

5. ábra. Az átviteli függvény a tervezett értékekkel

\section{Szimuláció, eredmények}

A szimulációt a 6. ábrán láthatjuk. A szimuláció MATLAB alapú grafikus fejlesztőkörnyezetben valósult meg (Simulinkben). Itt leginkább nem a Simulink, hanem a modernebb Simscape alkatrészei lettek lehelyezve. A félvezetők nem ideálisnak, hanem veszteségesnek lettek beállítva. Szabályozókör is készült, amelynek belső felépítését a 7. ábra mutatja. Beépített diszkrét PID szabályzó lett felhasználva, amelynek konstansai mérések alapján lett behangolva. A PID szabályzóra a kutatómunka nem tér ki részletesebben.

A kimeneten elhelyezett több száz vagy ezer $\mu \mathrm{F}$ kapacitású puffer kondenzátor nagy idóállandót ad a rendszernek, ezért a konverter bekapcsolásakor lágy felfutást kell alkalmazni. A lágy felfutás azt jelenti, hogy a kapcsolási frekvenciát a lehetö legnagyobb értéktől kell folyamatosan csökkenteni, így nem veszi igénybe a félvezetőket nagy áramtúlterhelés és a napelem feszültsége nem fog leesni a munkaponti feszültség alá. A két napelem együttes rövidzárási árama 17-18 A közé esik maximális fényintenzitás mellett. A lágy felfutás alkalmazása nélkül a rövidzárási áram többszörösére is szükség 
lehet. A rövidzárási munkapontban üzemeltetett napelem feszültsége a nullához tart, ami miatt a kimeneti feszültség is hasonlóan leesik. Abban az esetben, ha akkumulátort is alkalmazunk a napelemek mellett, akkor az indítás gyorsabban elvégezhető.

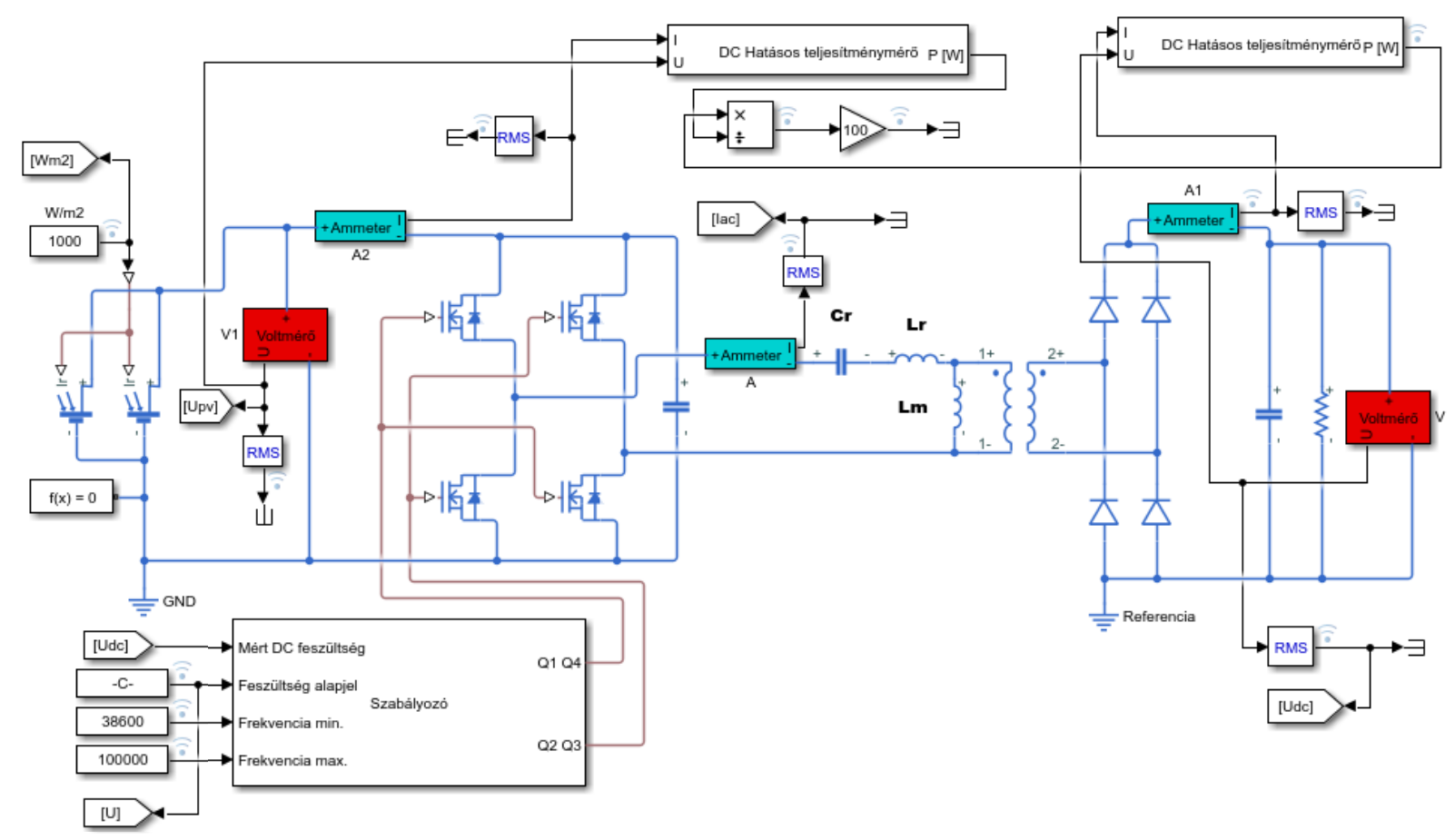

6. ábra. A szimuláció elrendezése Simulinkben

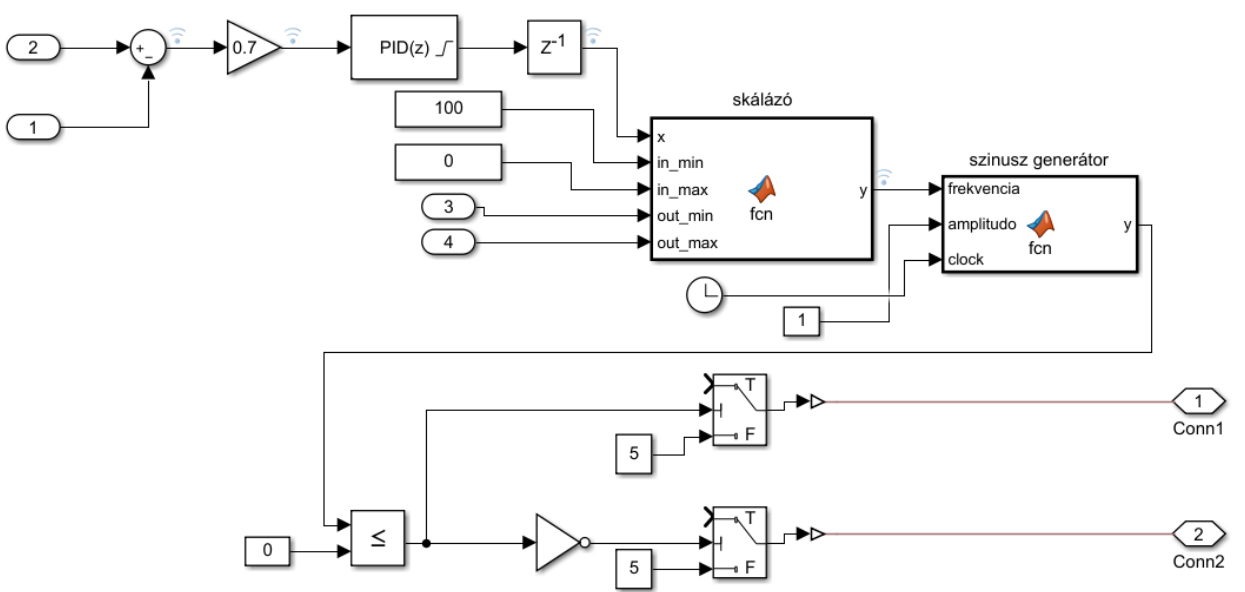

7. ábra. A szabályozó blokk belső felépitése

Tekintsük a 8 . ábrát, amely szemlélteti a szimulált kimeneti feszültséget, a beállított alapjelet és mindeközben a fényintenzitás értékét is. A kimeneti feszültséget a szabályzókör megfelelően beállítja a kívánt értékre, miközben a fényintenzitás dinamikusan változik. Az alapjel dinamikus változását is jól 
követi a szabályzó, a nagy időállandók a közbenső egyenáramú körben található kondenzátor miatt jön létre.
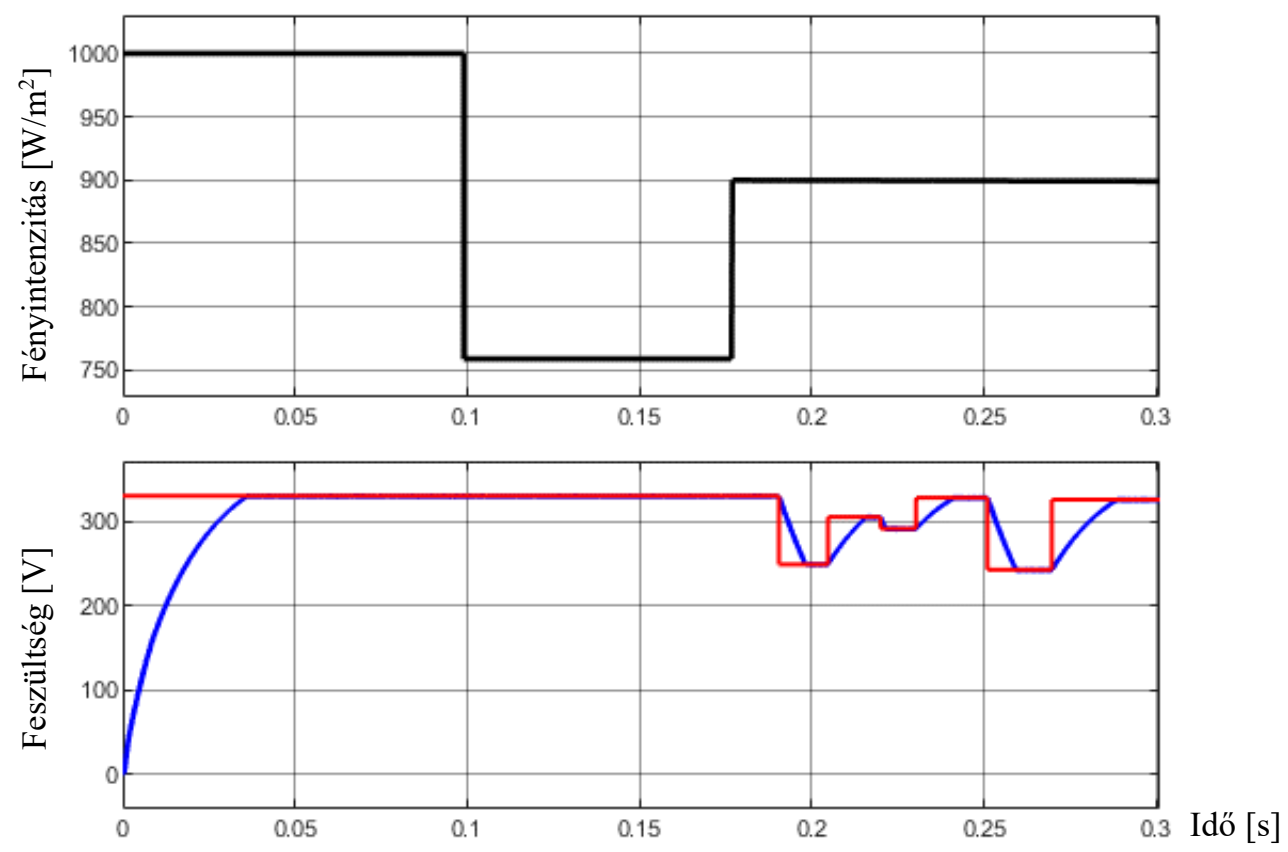

8. ábra. A szimulált kimeneti feszültség (kék), alapjel (piros) és fényintenzitás (fekete)

Átfogó eredményt ad még a 9. ábra, ahol konstansok formájában láthatjuk a szimulációs eredményeket. A hatásfok is megjelenik, amely a napelem teljesítménye és a kimeneti teljesítmény hányadosa százalékos értékben.

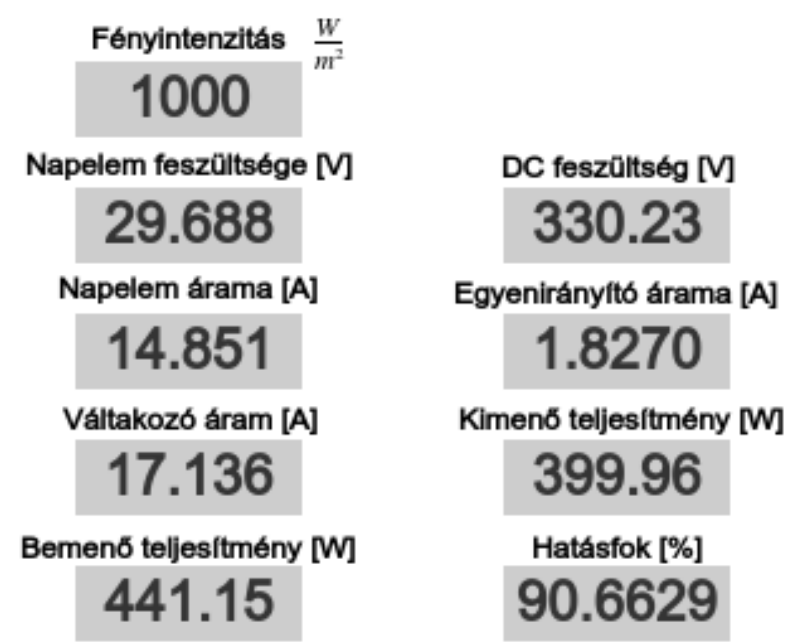

9. ábra. A szimulációs eredmények 


\section{Következtetések}

A kutató munka során szimulált eredmények bizonyítják az elméleti számítás helyességét, a behangolt PID szabályzó megfelelő müködését. Ezek alapján a gyakorlatban megépíthető a konverter a számított paraméterekkel. A több, mint $90 \%$-os hatásfok megfelelőnek bizonyul a valóságos paraméterekkel rendelkező félvezetők és passzív alkatrészek esetében.

\section{Köszönetnyilvánítás}

A cikkben ismertetett kutató munka az EFOP-3.6.1-16-2016-00011 jelü „Fiatalodó és Megújuló Egyetem - Innovatív Tudásváros - a Miskolci Egyetem intelligens szakosodást szolgáló intézményi fejlesztése" projekt részeként - a Széchenyi 2020 keretében - az Európai Unió támogatásával, az Európai Szociális Alap társfinanszírozásával valósul meg.

\section{Irodalomjegyzék}

[1] Infineon: Resonant LLC Converter: Operation and Design. 2012, p. 19.

[2] Fairchild: Half-Bridge LLC Resonant Converter Design Using FSFR-Series Fairchild Power Switch (FPSTM). 2007, p. 20.

[3] Fodor, D., Marschalko, R.: Korszerü teljesitményelektronika, 2014, p. 304.

[4] Bodnár, I.: Napelem müködésének alapjai, a napelemes villamosenergia-termelés elmélete és gyakorlati megvalósitása. Miskolci Egyetem, 2019, p. 108.

[5] Ashoka K. S. Bhat: Analysis and Design of LCL-Type Series Resonant Converter. IEEE Transactions on Industrial Electronics, Vol. 41, No. 1, Feb. 1994. https://doi.org/10.1109/41.281617

[6] Gu, Y., Lu, Z., Hang, L., Qian, Z., Huang, G.: Three-level LLC series resonant DC/DC converter. IEEE Transactions on Power Electronics Vol.20, July 2005, pp. 781-789. https://doi.org/10.1109/TPEL.2005.850921

[7] Yang, B., Lee, F. C., Concannon, M.: Over current protection methods for LLC resonant converter. APEC 2003, pp. 605-609. 